Effect of intake of virgin coconut oil (Cocos nucifera L.) on the spleen and small intestinal immune cells and liver lipid of mice

N. Komatsuzaki*, S. Arai, S. Fujihara and R.G.S. Wijesekara
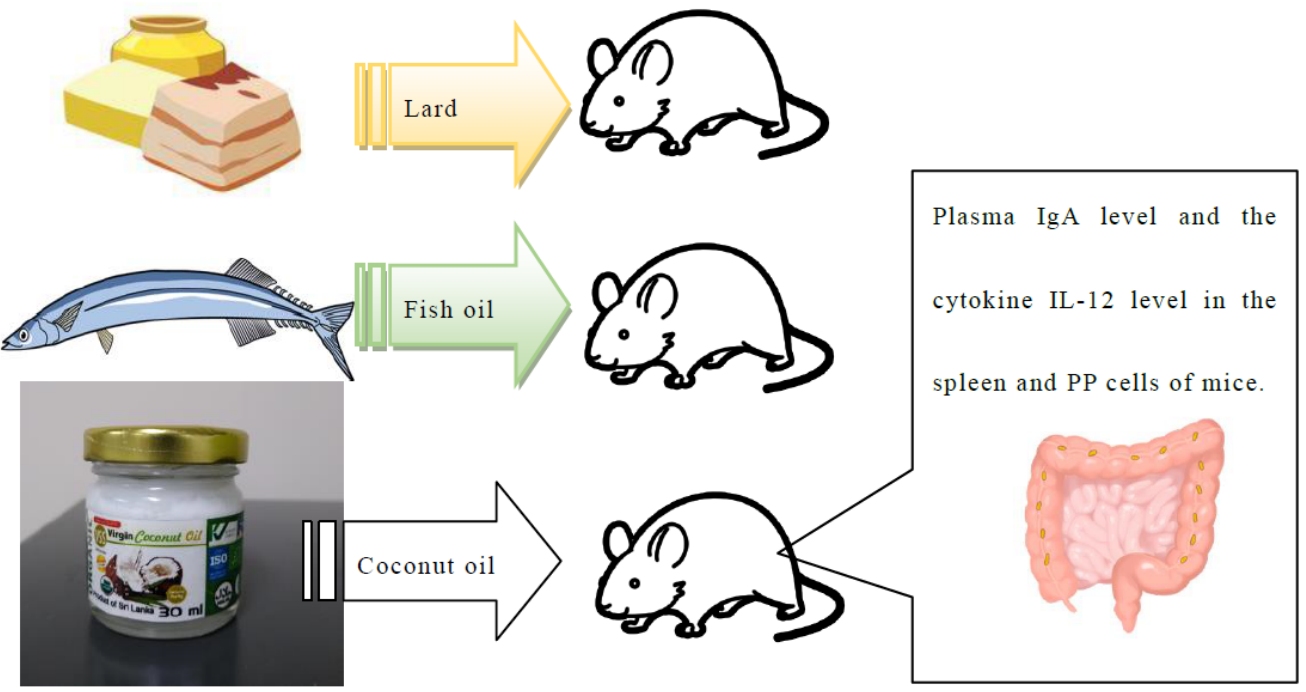

\title{
Highlights
}

- Feed lard diet, fish oil diet and coconut oil diet in mice for 6 weeks.

- Virgin coconut oil (Cocos nucifera L.) has a high proportion of medium-chain fatty acids (MCFAs).

- The cytokine IL-12 level in the spleen cells was highest in the C group, followed in order by the F and L groups. 


\title{
RESEARCH ARTICLE
}

\section{Effect of intake of virgin coconut oil (Cocos nucifera L.) on the spleen and small intestinal immune cells and liver lipid of mice}

\author{
N. Komatsuzaki ${ }^{1, *}$, S. Arai ${ }^{1}$, S. Fujihara ${ }^{1}$ and R.G.S. Wijesekara ${ }^{2}$ \\ ${ }^{1}$ Department of Human Nutrition, Seitoku University, 550 Iwase Matsudo, Chiba 271-8555, Japan. \\ ${ }^{2}$ Department of Aquaculture and Fisheries, Faculty of Livestock, Fisheries and Nutrition, Wayamba University of Sri \\ Lanka, Gonawila (NWP), 60170, Sri Lanka.
}

Received: 21/07/2020; Accepted: 13/01/2021

\begin{abstract}
Virgin coconut oil (Cocos nucifera L.) (VCO) is consumed worldwide and is rich in medium-chain fatty acids (MCFAs) and lauric acid (LA). The aim of this study was to examine the immuno-stimulation effect of VCO produced in Sri Lanka. Three groups of mice were fed either a lard diet (L), a fish-oil diet (F) or a coconut oil diet (C) for 6 weeks. During the experimental period, no significant differences in total food intakes or body weights of mice were observed among the three groups. Perirenal fat tissue weight, plasma Triacylglycerol (TG) level and total liver lipids were lower in the F group mice than those in the $\mathrm{L}$ and $\mathrm{C}$ group mice. The total cholesterol levels in livers of mice in the $\mathrm{C}$ group showed higher than that of the other groups. The cytokine IL-12 levels in spleen cells were highest in the $\mathrm{C}$ group mice, followed in order by the mice in $\mathrm{F}$ and $\mathrm{L}$ groups. Our studies clearly show that the plasma IgA and the cytokine IL-12 levels in the spleen and PP cells of mice increased in spite of the accumulation of liver lipids in mice by the intake of VCO produced in Sri Lanka.
\end{abstract}

Keywords: Coconut oil; medium-chain fatty acids; IL-12; lard; fish oil.

\section{INTRODUCTION}

Virgin coconut oil (Cocos nucifera L.), extracted from fresh coconut pulp is known to have a high proportion of medium-chain fatty acids (MCFAs), lauric acid (LA) and polyphenols with antioxidant activity (Cardoso et al., 2015). Coconut oil is easily absorbed and can be an excellent energy source for physical performance (Alves et al., 2015). The scientific literature has demonstrated benefits of extra virgin coconut oil to the reduction of (2011) diets rich in saturated fatty acids prepared with either palm oil or coconut oil and high in oleic acid did not alter postprandial or fasting plasma concentrations. Serum cholesterol, triglyceride and glucose levels were also found to be lower in virgin coconut oil (VCO) treated mice (Yeap et al., 2015).

We focused on the immune-stimulation effect of VCO from Sri Lanka, because this effect has been little studied to date. We examined the body and fat tissue weight, body fat (Lipoeto et al., 2004). In a study by Voon et al. plasma lipid concentration and plasma immunoglobulin A

(IgA) in the spleen and the small intestinal immune cells of mice. Peyer's patch (PP) cells from the small intestine and spleen cells were studied, and interleukin (IL)-12 level was investigated. We also compared the effects of coconut oil with those of lard and fish oil.

\section{MATERIALS AND METHODS}

\section{Animals and diets}

Fifty-four three-week-old male ICR mice were purchased from Japan SLC, Inc. (Shizuoka, Japan). All animals were housed individually in stainless steel cages under controlled conditions at a temperature of $22 \pm 1{ }^{\circ} \mathrm{C}$ and $50 \%$ relative humidity with a $12 \mathrm{~h}$ dark/light cycle (19:00-7:00). Animals were randomly divided into three dietary treatment groups with equal mean body weight: the lard diet (L) group $(n=18)$, the fish oil diet $(\mathrm{F})$ group $(\mathrm{n}=18)$, and the coconut oil diet (C) group $(\mathrm{n}=18)$. The experimental diet was based on the AIN-93G diet (Reeves et al., 1993). The composition of the fatty acid composition of the lard, fish oil and coconut oil diets are shown in Tables 1. It was added soybean oil ( $3 \mathrm{~g} / 100 \mathrm{~g}$ diet) avoid an n-6 fatty acid deficiency. Casein, lard, soybean oil and dietary components were obtained from Oriental Yeast Co., Ltd. (Tokyo, Japan). Fish oil was received from Nihon-Suisan (Tokyo, Japan), and VCO was purchased from VSS Products (PVT) Ltd. (Dankotuwa, Sri Lanka). The mice were fed the L, F or C diet for 6 weeks. Feed intake was recorded daily, and body weight was measured on alternate days. After feeding periods of two, four and six weeks, five mice were fasted for $16 \mathrm{~h}$ and sacrificed without affliction under ether anesthesia, and liver tissues and perirenal fat tissues were collected. Blood was collected by heart puncture with a heparinized syringe. The blood was maintained at $4{ }^{\circ} \mathrm{C}$ and centrifuged at 1,000 $\mathrm{g}$ for $15 \mathrm{~min}$. Plasma and liver samples were stored at -80 ${ }^{\circ} \mathrm{C}$ until they were analysed.

All procedures were performed in accordance with the Animal Experimentation Guidelines of the Laboratory Animal Care Committee of Seitoku University (No.192).

*Corresponding Author's Email: norikoma@wa.seitoku.ac.jp iD https://orcid.org/0000-0002-0190-3928 This article is published under the Creative Commons Attribution License (https://creativecommons.org/licenses/by/4.0/), which permits unrestricted use, distribution, and reproduction in any medium, provided the original work is properly cited. 
Table 1: Fatty acid composition of the diets (\% of total fatty acids)

\begin{tabular}{cccc}
\hline \hline Fatty acid & Lard diet & Fish oil diet & Coconut oil diet \\
\hline Saturated & 33.1 & 25.4 & 69.9 \\
Monounsaturated & 41.6 & 33.3 & 11.8 \\
Polyunsaturated & 25.2 & 37.8 & 18.2 \\
\hline Total n-6 & 22.8 & 17.9 & 16.3 \\
Total n-3 & 2.3 & 20.3 & 1.9 \\
\hline $\mathrm{n}-6 / \mathrm{n}-3$ & 9.9 & 0.9 & 8.6 \\
\hline \hline
\end{tabular}

Table 2: Body, liver and perirenal fat tissue weights

\begin{tabular}{|c|c|c|c|c|}
\hline Week & Group & Final body weight (g) & $\begin{array}{l}\text { Liver weight } \\
\text { (g/100 g B.W.) }\end{array}$ & $\begin{array}{c}\text { Perirenal fat tissue weight } \\
\text { (g/100 g B.W.) }\end{array}$ \\
\hline \multirow{3}{*}{2} & $\mathrm{~L}$ & $30.6 \pm 3.38$ & $6.02 \pm 0.61$ & $0.43 \pm 0.31$ \\
\hline & $\mathrm{F}$ & $33.0 \pm 4.11$ & $5.58 \pm 0.74$ & $0.37 \pm 0.18$ \\
\hline & $\mathrm{C}$ & $33.5 \pm 2.11$ & $5.51 \pm 0.49$ & $0.50 \pm 0.23$ \\
\hline \multirow{3}{*}{4} & $\mathrm{~L}$ & $41.5 \pm 6.13$ & $4.73 \pm 0.05$ & $0.67 \pm 0.38$ \\
\hline & $\mathrm{F}$ & $39.0 \pm 5.04$ & $4.53 \pm 0.28$ & $0.70 \pm 0.21$ \\
\hline & $\mathrm{C}$ & $38.3 \pm 8.01$ & $4.46 \pm 1.33$ & $0.69 \pm 0.28$ \\
\hline \multirow{3}{*}{6} & $\mathrm{~L}$ & $46.1 \pm 5.40$ & $3.73 \pm 0.41$ & $1.06 \pm 0.10^{\mathrm{a}}$ \\
\hline & $\mathrm{F}$ & $40.6 \pm 3.30$ & $3.87 \pm 0.43$ & $0.72 \pm 0.30^{\mathrm{b}}$ \\
\hline & $\mathrm{C}$ & $43.6 \pm 4.20$ & $3.71 \pm 0.24$ & $1.11 \pm 0.23^{\mathrm{a}}$ \\
\hline
\end{tabular}

Values represent mean $\pm \mathrm{SD}(\mathrm{n}=5)$. Within a grouping, values not sharing a common superscript letter are significantly different at $\mathrm{p}$ $<0.05$.

\section{Biochemical assays of plasma and liver}

Liver lipids were extracted following the method described by Folch et al. (1996). Triacylglycerol (TG), total cholesterol (T-cho) concentrations in plasma, and liver extracts were measured using test kits (Triglyceride E-tests Wako and Cholesterol E-tests were purchased from Wako Pure Chemical Industries, Ltd., Osaka, Japan). The IgA level of plasma in mice was measured using test kits (Mouse IgA ELISA Kit, ICL, Inc., Portland, OR, USA).

\section{Cytokine analysis}

Cells were prepared following the procedure described by Aoki-Yoshida et al. (2016). Cells were cultured in RPMI1640 (Nissui Pharmaceutical, Tokyo, Japan) containing 10\% fetal calf serum (FCS; GIBCO, Grand Island, NY, USA), 2 g/L NaHCO, $100 \mathrm{U} / \mathrm{mL}$ penicillin, $100 \mu \mathrm{g} / \mathrm{mL}$ streptomycin, $50 \mu \mathrm{M} 2$-mercaptoethanol, and $300 \mathrm{mg} / \mathrm{L} \mathrm{L}$-glutamine at $37^{\circ} \mathrm{C}$ in $5 \% \mathrm{CO}_{2}$ in the air.

PP cells from ICR mice fed for 6 weeks were isolated from the small intestines as follows, PP cells were removed from the small intestines and washed with Roswell Park Memorial Institute (RPMI) (+). The PP cells were crushed in RPMI (+) treated with $1 \mathrm{mg} / \mathrm{mL}$ collagenase IV (Sigma Aldrich, St Louis, MO, USA) in a $50 \mathrm{~mL}$ tube with gentle stirring at $37^{\circ} \mathrm{C}$ in the air for $60 \mathrm{~min}$. After collagenase treatment, the preparation was filtered with gauze and the cells were washed with Phosphate-buffered saline (PBS) followed by centrifugation at $4{ }^{\circ} \mathrm{C}$ and, $1300 \mathrm{rpm}$ for $5 \mathrm{~min}$. The supernatant was suspended with $1 \mathrm{~mL}$ of RPMI (+).

Spleen cells were crushed in $5 \mathrm{~mL}$ of RPMI $(+)$ and filtered with gauze. The cell suspension was then centrifuged at $4{ }^{\circ} \mathrm{C}$ and, $1300 \mathrm{rpm}$ for $5 \mathrm{~min}$. The supernatant was suspended with $1 \mathrm{~mL}$ of RPMI (+).

One hundred $\mu \mathrm{L}$ of isolated PP cells $\left(1 \times 10^{5}\right.$ cells/well $)$ and spleen cells $\left(1 \times 10^{5}\right.$ cells/well $)$ were added in a 96 -well flat-bottomed plate. Determination of the IL-12 level in the supernatants was performed by a sandwich enzyme-linked immunosorbent assay (ELISA). The mouse IL-12 ELISA Ready-SET-Go! (eBioscience, Inc., San Diego, CA, USA) was used according to the manufacturer's instructions.

\section{Statistical analysis}

Values were expressed as means $\pm \mathrm{SD}$. Repeated-measures analysis of variance (ANOVA) was used to evaluate the effects of groups. Differences in mean values between groups were tested by Scheffe's multiple range test. A $p$-value of less than 0.05 was considered statistically significant. 


\section{RESULTS}

\section{Body, liver and perirenal fat tissue weights}

No significant differences in final body weight or liver weight were observed among the three groups (Table 2). There were no significant differences in perirenal fat tissue weights were observed among the three groups up to 4 weeks. However, weights in the $\mathrm{F}$ group at 6 weeks were lower than those of the $\mathrm{L}$ and $\mathrm{C}$ groups $(p<0.05)$.

\section{Liver, plasma lipids and plasma IgA profiles}

During the experimental period, there were no significant differences in liver TG concentration among mice in the three groups (Figure 1b). No differences were observed in total lipids or in liver T-cho concentrations among three groups until 4 weeks. The total lipids or the liver T-cholesterol concentrations in the $\mathrm{C}$ group at 6 weeks showed higher levels than those in the $\mathrm{L}$ and $\mathrm{F}$ groups (Figure 1a, c) $(p<0.05)$.

On the other hand, the plasma TG concentration in the $\mathrm{F}$ group was lower than those in the $\mathrm{L}$ and $\mathrm{C}$ groups at 6 weeks (Figure 2a) $(p<0.05)$. Additionally, the plasma T-cho concentrations in the $\mathrm{F}$ group were lower than those in the $\mathrm{L}$ and $\mathrm{C}$ groups at both 2 and 6 weeks (Figure $2 \mathrm{~b})(p<0.05)$. No differences were observed in plasma IgA levels among

(a)

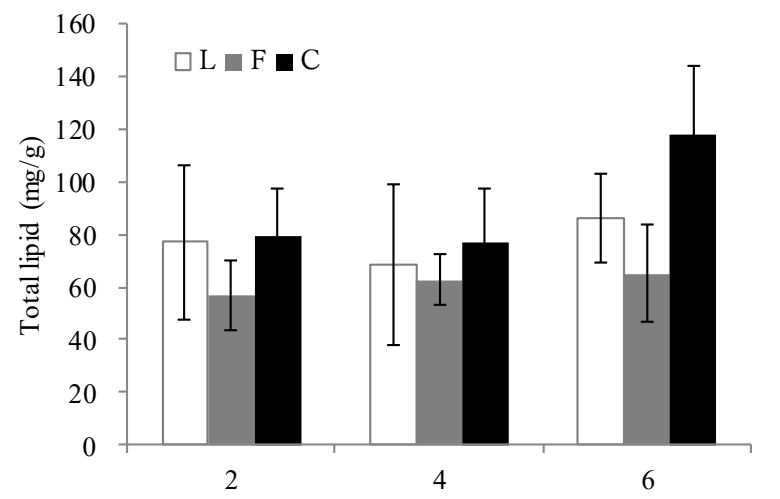

(c) the three groups up to 2 weeks. However, plasma IgA levels of the $\mathrm{F}$ and $\mathrm{C}$ groups showed higher levels at 4 weeks than that of the L group (Figure $2 \mathrm{c})(p<0.05)$.

\section{IL-12 levels of spleen and PP cells}

The cytokine IL-12 level in the spleen cells was highest in the $\mathrm{C}$ group, followed in order by the $\mathrm{F}$ and $\mathrm{L}$ groups (Figure 3a) $(p<0.05)$. Level of the cytokine IL-12 in the $\mathrm{PP}$ cells of the $\mathrm{C}$ group was higher than that in the $\mathrm{L}$ and $\mathrm{F}$ groups (Figure $3 \mathrm{~b})(p<0.05)$.

\section{DISCUSSION}

Fish oil is known to reduce plasma TG levels in patients with hyperlipidemia and is useful for improving CVD (Nestel et al., 1990; Guichardant et al., 2015). The lipidlowering action of n-3 PUFAs results primarily from the inhibition of lipogenesis and the stimulation of FA oxidation in the liver (Halminski et al., 1991; Komatsuzaki et al., 2010). Nakashima et al. (2009) report that plasma lipid concentrations in mice fed a fish oil diet for 6 weeks were lower than those in mice fed a lard diet. The present experimental results also showed that perirenal fat tissue weight, plasma $\mathrm{TG}$, and $\mathrm{T}$-cho concentrations in the $\mathrm{F}$ group were lower than those in the $\mathrm{L}$ and $\mathrm{C}$ groups at 6 weeks (Table 3, Figure 2a, b) $(p<0.05)$.

(b)
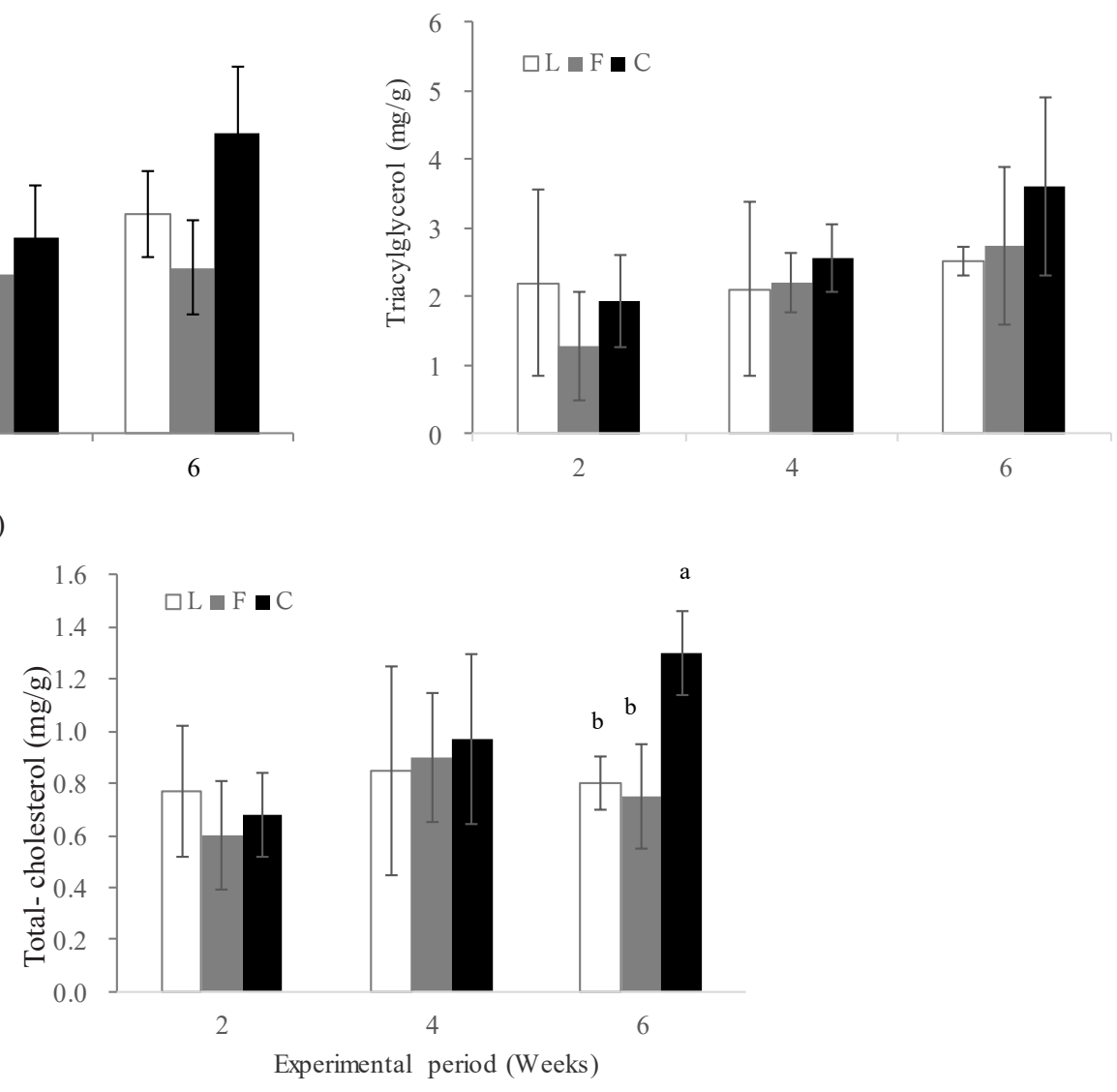

Figure 1: Liver lipids in mice fed experimental diets; L: lard diet; F: fish oil diet; C: coconut oil diet. Values represent mean \pm $\mathrm{SD}(\mathrm{n}=5)$. Within a grouping, values not sharing a common superscript letter are significantly different at $p<0.05$. 
(a)

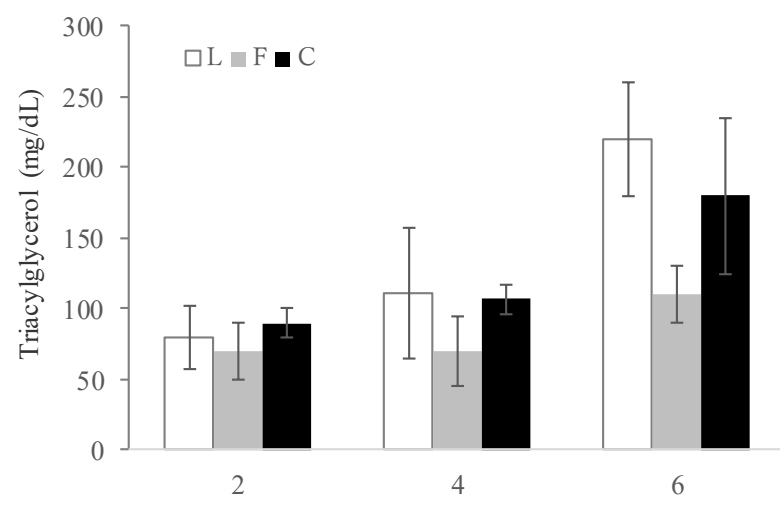

(b)

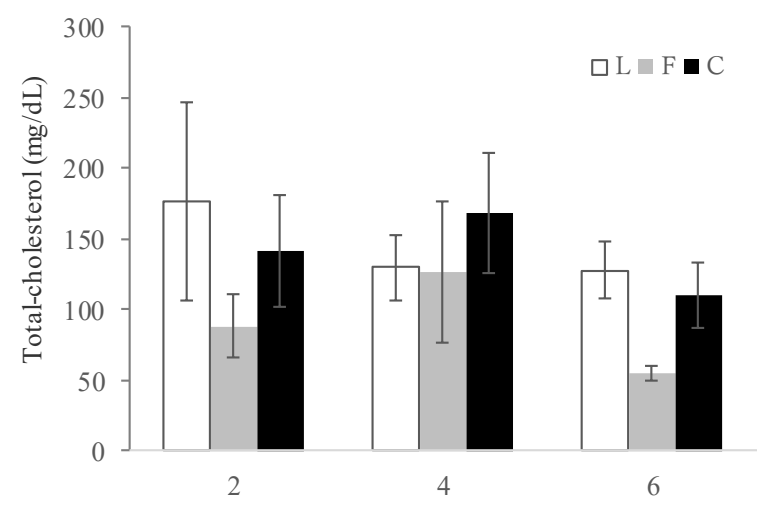

(c)

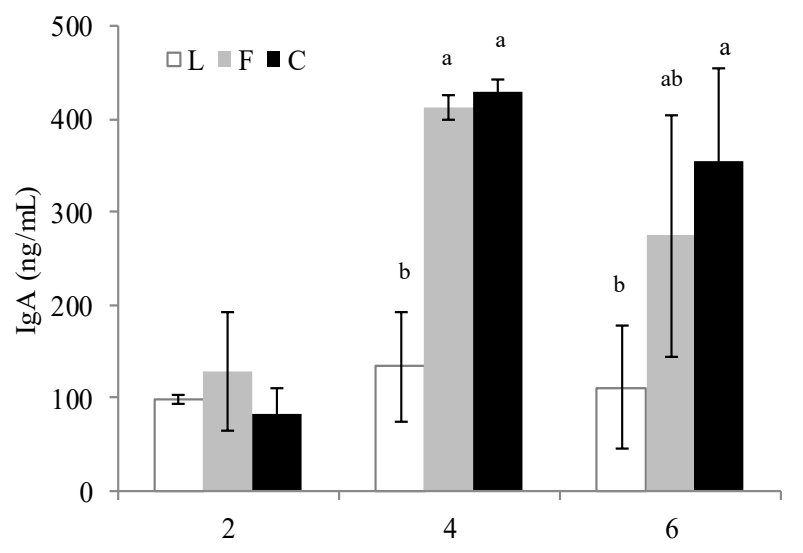

Experimental period (weeks)

Figure 2: Plasma lipids and IgA levels in mice fed experimental diets. L: lard diet; F: fish oil diet; C: coconut oil diet.Values represent the mean $\pm \mathrm{SD}(\mathrm{n}=5)$. Within a grouping, values not sharing a common superscript letter are significantly different at $p<$ 0.05 .

(a)

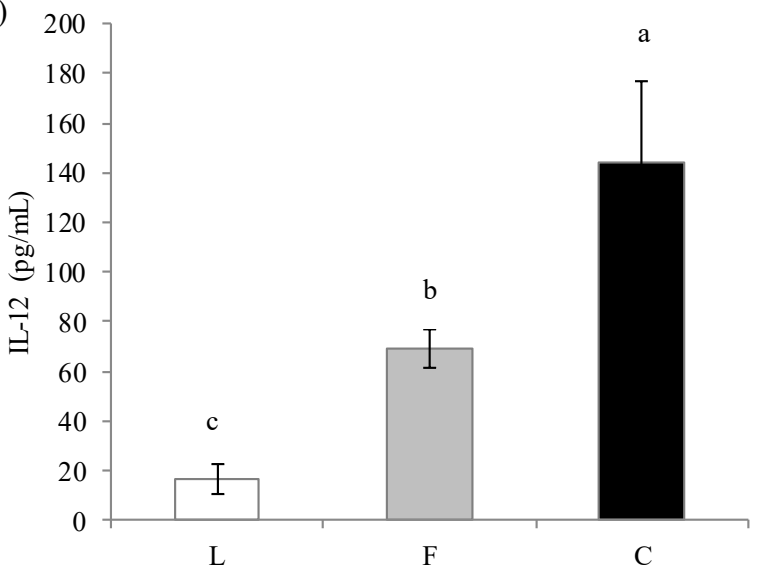

(b)

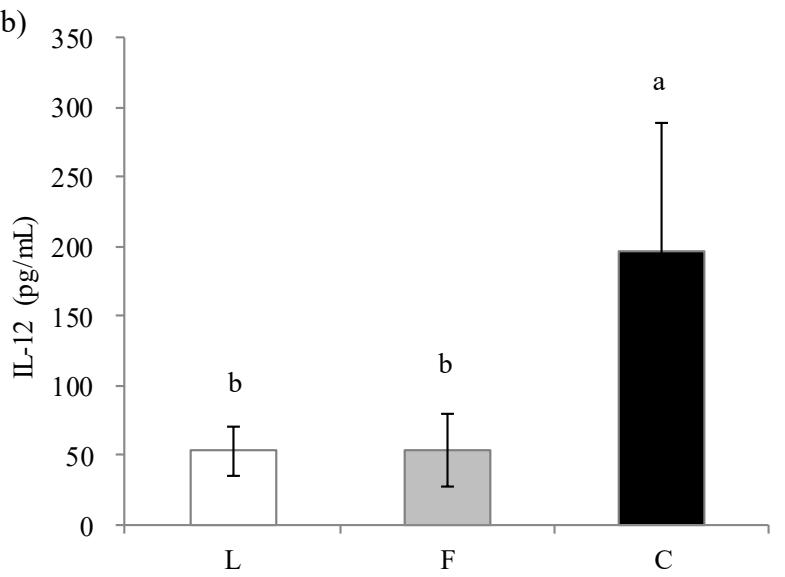

Figure 3: Production of the cytokine IL-12 in the spleen cells and Peyer's patch (PP) cells in mice fed experimental diets after 6 weeks; (a) spleen cells. (b) PP cells. L: lard diet; F: fish oil diet; C: coconut oil diet. Values represent the mean $\pm \mathrm{SD}(\mathrm{n}=5$ ). Within each panel, values not sharing a common superscript letter are significantly different at $p<0.05$. 
On the other hand, the effect of the hypolipidemic action of coconut oil was not observed as well as the effect of lard (Figure 2a, b). The total lipids and liver T-cho concentrations in the $\mathrm{C}$ group at 6 weeks were 118 $\pm 26 \mathrm{mg} / \mathrm{g}$ and $1.3 \pm 0.2 \mathrm{mg} / \mathrm{g}$, respectively (Figure 1a, c) $(p<0.05)$, and liver T-cho concentrations in the $\mathrm{C}$ group was twice as high as those in the L group at 6 weeks. MCFAs are absorbed intact from the small intestine, and do not undergo degradation or re-esterification processes (Pehowich et al., 2000). They are transported to the liver through the portal vein like glucose and amino acids, which are degradation products of sugar and proteins respectively (McCarty et al., 2016). LA concentrations in mice fed the lard diet and the coconut oil diet in the present experiment were $0.1 \%$ and $34.3 \%$, respectively. This demonstrates clearly that fats can easily accumulate in the liver of mice fed coconut oil for a long time.

Plasma IgA levels in the $\mathrm{F}$ and $\mathrm{C}$ groups were found to have increased at 4 weeks after the start of feeding (Figure 2c). $\operatorname{IgA}$ is present in the blood, intestinal tract and mother's milk, and plays an important role in immunity. It has been reported that fish oil enhances intestinal IgA and B cell functions in vivo (Gurzell et al., 2013). It is important to investigate whether the coconut oil has an immune-stimulating effect, as DHA does.

Recent experimental studies on VCO suggest antioxidant, anti-inflammatory, and immunostimulatory effects of VCO (Voon et al., 2011; Nair et al., 2016). The cytokine IL-12 produced by immune cells works to activate important cell-mediated immunity factors in the early period of infection (Komatsuzaki et al., 2017). In order to clear the immune-stimulation effect of coconut oil, the IL-12 production of the spleen cells and intestinal PP cells of mice was investigated. IL-12 levels in the spleen and the PP cells of the C group were $144 \pm 33 \mathrm{pg} / \mathrm{mL}$ and 197 $\pm 91 \mathrm{pg} / \mathrm{mL}$, respectively (Figure 3 ) and notably, the IL12 level of spleen cells in the $\mathrm{C}$ group was approximately twice that in the $\mathrm{F}$ group (Figure $3 \mathrm{a}$ ). According to Voon et al. (2011), no significant difference was observed in the effects of a coconut oil diet containing LA (8.5\%) on serum inflammatory markers such as tumor necrosis factor (TNF) $-\alpha$ IL-6 and interferon (IFN)- $\gamma$. In the present study, the LA composition of the diets of the C group was $34.3 \%$ (Table 2). When adding 6-10C other than LA, the total MCFA in the coconut oil diet was $46.9 \%$. There are many immunologically active substances in the spleen and PP cells. IL-12 production was detected in both spleen and PP cells in the $\mathrm{C}$ group in this experiment, and we speculate that the LA contained in the coconut oil induces cytokine production.

Ye et al. (2020) reported that plasma IL-12 levels were increased in many types of atherosclerosis and atherosclerotic cardiovascular diseases. It was speculated that the accumulation of perirenal fat tissues and the increased plasma lipids in the $\mathrm{C}$ group stimulated the PP cells and then the plasma IL-12 levels. Therefore, it was suggested that VCO was one of the factors causing cardiovascular diseases although it activated immune cells in the $\mathrm{C}$ group.
In a recent report, the polyphenols in VCO were found to be contributed to the prevention of Alzheimer's disease (Chatterjee et al., 2020). Thus, further research is needed on the health effects of VCO. LA is known to exhibit antimicrobial activity against some bacteria, but it is unclear whether the antimicrobial activity of VCO is comparable to that of LA (Nagase et al., 2017). In future research, we would like to examine the antimicrobial activity of VCO in greater details.

\section{CONCLUSION}

The present study clearly shows that the plasma IgA and the cytokine IL-12 levels in the spleen and PP cells of mice increased in spite of accumulation of liver lipids in mice by the intake of VCO produced in Sri Lanka.

\section{ACKOWLEDGEMENT}

We thank Nihon-Suisan (Tokyo) for providing the fish oil.

\section{DECLARATION OF CONFLICT OF INTEREST}

The authors have no financial conflicts of interest to report.

\section{REFERENCES}

Alves, N.F., Porpino, S.K., Monteiro, M.M. Gomes, E.R. and Braga, V.A. (2015). Coconut oil supplementation and physical exercise improves baroreflex sensitivity and oxidative stress in hypertensive rats. Applied Physiology, Nutrition and Metabolism 40(4): 393-400. DOI: 10.1139/apnm-2014-0351.

Aoki-Yoshida, A., Yamada, K., Hachimura, S., Sashihara, T., Ikegami, S., Shimizu, M. and Totsuka, M. (2016). Enhancement of oral tolerance induction in DO11.10 mice by Lactobacillus gasseri OLL2809 via increase of effector regulatory T cells. PLOS ONE 11(7): 0158643. DOI: 10.1371/journal.pone.0158643.

Cardoso, D.A., Moreria, A.S.B., Oliveira, G.M.M., Raggio, L.R. and Rosa, G. (2015). A coconut extra virgin oilrich diet increases HDL cholesterol and decreases waist circumference and body mass in coronary artery disease patients. Nutricion Hospitalaria 32(5): 21442152. ISSN 0212-1611.

Folch, J., Lees, M. and Sloane-Stanley, G.H. (1996). A simple method for the isolation and purification of total lipids from animal tissues. Journal of Biological Chemistry 226(1): 497-509. PMID: 13428781.

Guichardant, M., Calzada, C., Bernoud-Hubac, N., Lagarde, M. and Vericel, E. (2015). Omega-3 polyunsaturated fatty acids and oxygenated metabolism in atherothrombosis. Biocimica et Biophysica Acta 1851(4): 485-495. DOI: 10.1016/j.bbalip.2014.09.013.

Gurzell, E.A., Teague, H., Harris, M., Shaikh, S. and Fenton, J.I. (2013). DHA-enriched fish oil targets B cell lipid microdomains and enhances ex vivo and vivo $\mathrm{B}$ cell function. Journal of Leukocyte Biology 93(4): 463470. DOI: 10.1189/jlb.0812394.

Halminski, M.A., Marsh, J.B. and Harrison, E.H. (1991). Differential effects of fish oil, safflower oil and palm oil on fatty acid oxidation and glycerolipid synthesis in rat liver. Journal of Nutrition 121(10): 1554-1561. DOI: 10.1093/jn/121.10.1554. 
Komatsuzaki, N., Usui, T., Toriumi, E., Yamada, Y. and Nakashima, Y. (2010). Effect of dietary lard and fishoil intake by rats during pregnancy and lactation on the composition of stomach contents and plasma lipid concentration in pups. Journal of Japan Society of Nutrition and Food Sciences 63(3): 107-114. ISSN: 1883-2849.

Komatsuzaki, N., Aoki-Yoshida, A and Shima, J. (2017). Effects of live Lactobacillus paracasei NFRI 7415 on the intestinal immune system and intestinal microflora of mice. International Journal of Biotechnology and Food Sciences 5(4): 56-62. DOI: 10.33495/ijbfs.

Lipoeto, N.I., Agus, Z., Oelzil, F., Wahlqvist, M.L. and Wattanapenpaiboon, N. (2004). Dietry intake and the risk of coronary heart disease among the coconutconsuming Minangkabau in West Sumatra, Indonesia. Asia Pacific Journal of Clinical Nutrition 13(4): $377-$ 384. PMID: 15563444.

McCarty, M.F. and DiNicolantonio, J.J. (2016). Lauric acid-rich medium-chain triglycerides can substitute for other oils in cooking applications and may have limited pathogenicity. Open Heart: British Cardiovascular Society 3: e000467. DOI: 10.1136/ openhrt-2016-000467.

Nagase, K., Mori, Y. and Sugitani, K., (2017). Comparison of the antimicrobial spectrum and mechanism of organic virgin coconut oil and lauric acid against bacteria. Journal of Wellness and Health Care 41: 87-95. ISSN: 24333190.

Nair, S.S., Manalil, J.J., Ramavarma, S.K., Suseela, I.M., Thekkepatt, A. and Raghavamenon, A.C. (2015). Virgin coconut oil supplementation ameliorates cyclophosphamide-induced systemic toxicity in mice. Human and Experimental Toxicology 35(2): 205-212. DOI: $10.1177 / 0960327115578867$.

Nakashima, Y., Sato, A. and Saito, M. (2009). Effect of plant- and fish-oil derived n-3 polyunsaturated fatty acids on counteraction of n-3 fatty acid shortage in adult rats fed a lard diet. Journal of Nutritional Science and Vitaminology 2009; 55:346-352. ISSN: 1881-7742.
Nestel, P.J. (1990). Effects of n-3 fatty acids on lipid metabolism. Annual Review of Nutrition 10: 149-167. DOI: 10.1146/annurev.nu.10.07190.001053.

Ota, N., Soga, S., Hase, T., Tokimitsu, I. and Murase, T. (2007). Dietary diacylglycerol induces the regression of atherosclerosis in rabbits. Journal of Nutrition 137(5): 1194-1199. DOI: 10.1093/jn/137.5.1194.

Pehowich, D.J., Gomes, A.V. and Barnes, J.A. (2000). Fatty acid composition and possible health effects of coconut constituents. West Indian Medical Journal 49(2): 128133. PMID: 10948851.

Reeves, P.G., Nielsen, F.H. and Fahel, Jr.G.C. (1993). AIN93 purified diets for laboratory rodents: final report of the American Institute of Nutrition Ad Hoc Writing Committee on the reformulation of the AIN-76A rodent diet. Journal of Nutrition 123(11): 1939-1951. DOI: 10.1093/jn/123.11.1939.

Voon, P.T., Ng, T.K., Lee, V.K. and Nesaretnam, K. (2011). Diets high in palmitic acid (16:0), lauric and myristic acids $(12: 0+14: 0)$, or oleic acid $(18: 1)$ do not alter postprandial or fasting plasma homocysteine and inflammatory markers in healthy Malaysian adults. American Journal of Clinical Nutrition 94(4): 14511457. DOI: 10.3945/ajen.111.020107.

Yeap, S.K., Beh, B.K., Ali, N.M., Yusof, H.M., Koh, S.P., Alitheen, N.B. and Long, K. (2015). Antistress and antioxidant effects of virgin coconut oil in vivo. Experimental and Therapeutic Medicine 9(1): 39-42. DOI: 10.3892/etm.2014.2045.

Ye, J., Wang, Y., Wang, Z., Liu, L., Yang, Z., Wang, M., Xu, Y., Ye, D., Zhang, J., Lin, Y., Ji, Q. and Wan, J. (2020). Roles and mechanisms of interleukin-12 family members in cardiovascular diseases: opportunities and challenges. Frontiers in Pharmacology 11: 129. DOI: 10.3389/fphar.2020.00129. 